\title{
Pork-Barrel versus Irrelevance Effects in Portuguese Public Spending
}

Author:

Paulo Reis Mourao, Ph.D.

(http://www.eeg.uminho.pt/economia/paulom/ )

Department of Economics

Economics \& Management School

University of Minho

4700 Braga - Portugal

\begin{abstract}
$^{1}$ :
Pork-barrel effects are discussed using a specific program of Portuguese investment expenditures (PIDDAC) that has been observed since 1997. Our framework adds new insight to this important branch of Economics literature. First, our analysis is the first to be based on Sequential Dictators Games, which are more appropriate for studying the strategies of the agents involved in pork-barrel practices. Second, we examine the role of 'irrelevance effects', which limit or offset the pork-barrel effect even if the recipient municipality and the Portuguese Government are ruled by the same political wing. Our empirical estimations confirm that the Portuguese government tends to increase PIDDAC transfers to the municipalities that are being ruled by the same political wing. Municipalities with fewer residents or fewer parishes tend to suffer the most significant irrelevance effects. PIDDAC transfers to all municipalities were found to be more generous during election years.
\end{abstract}

Key-Words: Pork Barrel policies; Inequality; Public Spending

\footnotetext{
${ }^{1}$ The author is indebted to two anonymous referees of Environment and Planning $C$ for helpful comments on a previous version of this research. Any remaining errors are due to the author alone.
} 


\section{Introduction}

It is common practice for people to compensate their friends for their support. Typically, people give different gifts to different friends, with closer friends receiving more expensive gifts. Governments and politicians behave in the same way. As managers of public resources funded by all taxpayers, governments and politicians are in charge of and accountable for a type of responsibility that is very different from that of ordinary citizens. Additionally, as will be discussed in this paper, such strictly monitored interactions have inefficiency costs that are hardly compensated by the private political gains earned by incumbents or politicians who exhibit this pork-barrel behavior.

In this paper, the literature on pork-barrel behavior is discussed in the context of the Portuguese decentralized (and discretionary) public structure - the PIDDAC. PIDDAC has been a program that details the annual investment expenditures that the Portuguese government allocates for the development of specific areas. The pattern of resource distribution under this program is first discussed using a public economics framework. Based on the close fit of this framework to the PIDDAC, this paper serves as a first attempt to discuss and analyze this important Portuguese program in the context of the literature on pork-barrel effects and in consideration of factors that control pork-barrel effects. Until now, to the best of our knowledge, none of the previous models of porkbarrel strategies has included these controls that are critical in terms of explaining why a jurisdiction ruled by the Government party might receive less than would be expected.

Following the existing literature, we refer to these control effects as irrelevance effects'. Irrelevance effects reduce or partially control pork-barrel effects because even if a given government is more closely related to a given political party, the government will surely not grant all the municipalities ruled by that party with the same amount of PIDDAC resources. Just as citizens do not remember the birth dates of all of their most distant friends, governments attribute different levels of importance to different municipalities. 
In the context of Game Theory, we realize that PIDDAC transfers can be perceived as Dictator Games in which government officials decide on the way in which the public resource pie should be distributed. Given the tendency for the government to be dominated by alternating political parties, pork-barrel behavior may be conceptualized as an example of Sequential Dictator Games. More specifically, the payoffs matrices associated with each municipality depend on multiple factors, including the net benefit of PIDDAC transfers, the political party ruling the government, and the simultaneity of rule (i.e., the ruling party also rules the municipality). We detail these payoffs for the four possible scenarios based on combining the Right/Left political parties ruling the Portuguese government and the Right/Left political parties ruling Portuguese municipalities since 1997.

The rest of the paper is structured as follows: In Section 2, we describe the history and the distribution of PIDDAC resources. In Section 3, we introduce our theoretical model. In Section 4, we provide details about our empirical framework, the database and the results. In Section 5, we conclude the paper based on our findings.

\section{The history and distribution of PIDDAC expenditures}

\section{1 - The PIDDAC history}

The PIDDAC ('Programa de Investimentos e Despesas de Desenvolvimento da Administração Central', or, in English, the Program of Investments and Development Expenditures of the Central Administration) was launched in the early $1980 \mathrm{~s}^{2}$. During

\footnotetext{
${ }^{2}$ Oliveira Martins et al (2007) noted that Law 64/77 had already allowed the presentation of certain capital outlays in tables of multiannual programs. However, it was not until the 1980s that the Portuguese Public Budget Reports began to present details on program outlays consistently.
} 
that period, Portuguese Public Budget Reports began to include details about the investment expenditures directly made by the government to decentralized departments at the ministry or municipality levels (Fernandes, 1984). Nevertheless, it was after the establishment of the first Quadro Comunitário de Apoio (in English, Community Support Framework) that PIDDAC expenditures began appearing as a separate section of the Budget Report. With the increasing role of the European Community (mainly by FEDER co-participation) in PIDDAC funding, the Public Budget Regulation Law (Law 91/2001, art. $29^{\circ}$ ) stated that the PIDDAC Tables should include the related (nationally funded) expenditures in terms of Major Planning Options (Grandes Opções do Plano) and the Community Support Framework (Quadro Comunitário de Apoio). In other words, the law required the various costs and the funding sources, by region and for multiple years, to be highlighted in the tables.

According to Law 40/83 (art. $12^{\circ}$, n⿳3), the PIDDAC values appear in table VII as program-based multiannual charges.

The importance of PIDDAC distributions has increased so significantly that in the 1990s, the Portuguese legislation treated these investment outlays as important enough to be reported in the form of specific and required documents. Specifically, as mandated by Law 8/1990, art. $8^{\circ}$ n.2 (LBCP, Lei de Bases da Contabilidade Pública, or Bases Law for Public Accounting), Public Organizations are required to report to the Ministry of Finances all of their expenditures that have been funded by PIDDAC resources.

Moreover, Law 6/1991 (art. 12 ${ }^{\circ}, n^{\circ} 1$ ) brought about a special innovation by requiring the inclusion of PIDDAC tables in Table XI of the Public Budget Report. This marked the first time that the Regulation Budget Law required the separate identification of PIDDAC values (i.e., by its own denomination). As a result, the PIDDAC tables began to include details about sub-programs, specific projects, and the main localities that received funding in relation to their sources of funding (i.e., from the Portuguese government or the European Community).

Law 91/2001 also followed the mandates in the previous Budget Regulation Law (Law 6/1991) regarding PIDDAC. However, the previous Table XI was renamed as Table $\mathrm{XV}$, which continued to detail PIDDAC distributions by sub-programs, projects and main areas of implementation. 
In addition, responding to article 75 of Law 91/2001 (or the revoked Law 6/91), the distribution of PIDDAC values was to be reported at the annual General State of the Portuguese Accounts (Conta Geral do Estado).

Since 2001, however, Law 91/2001 has been revised: two paragraphs directly related to the PIDDAC Tables have been rewritten. Specifically, Law 48/2004 (article 29) allows the Public Budget Reports to show local implementations of PIDDAC sub-programs and projects by macro-regions only (NUTS 2). Although this accommodation (Law 48/2004) has been available since 2004, the 2012 Portuguese Public Budget Report was the first to take advantage of this opportunity. Finally, for the first time, Law 22/2011 omits any reference to PIDDAC and clearly identifies Table XV of the Public Budget Report as merely a descriptive table of public expenditures corresponding to specific programs (see arts. 19 and 32).

Although the cited legislation has always required program expenditures to be made on the principles of efficacy and efficiency (article 19 of Law 22/2011; article 19 of Law 48/2004; article 16 of Law 91/2001), PIDDAC values have long been suspected and criticized for favoring certain lobbies or areas over others. For example, the public has raised doubts about the efficacy and efficiency of using PIDDAC to support the extensive repair of one public school in a given municipality when consideration had not been given to a school that was built at the same time in a neighboring municipality.

\section{2 - The PIDDAC distribution}

As argued in sub-section 2.1, public opinion (namely, opinions expressed by the press) has described the distribution of PIDDAC resources as closely connected with political and party objectives. As shown in Table 1, the share of PIDDAC transfers is not proportional to the share of electors living in given Portuguese districts (groups of municipalities). Specifically, some of these districts (Braga, Leiria, or Madeira) typically have received a lower percentage of PIDDAC funding than the percentage of electors living in them, whereas other districts (Beja, Faro, and Portalegre) typically have received a higher percentage of PIDDAC funding than the percentage of electors living in them. 


\section{[INSERT HERE TABLE 1]}

The next figure presents the concentration index (Gini Index) of PIDDAC distribution for Portuguese municipalities since 1997. The increase in concentration since the first observations indicates that some municipalities have received preferential treatment from the Portuguese government with regard to the distribution of these capital expenditures.

\section{[INSERT HERE FIGURE 1]}

Taken together, the trend of certain municipalities being favored over others and the trend of increasing concentration jointly reinforce the suspicion that PIDDAC distributions may be caused by factors other than the distribution of electors and population density. In the next section, we will identify and discuss these other factors.

Furthermore, this study of the factors driving the PIDDAC distribution highlights specific topics in public economics literature, namely pork-barrel effects. In fact, as discussed in the following sections, this literature has focused precisely on the trend of favoring certain regions or jurisdictions because of their political affinity to the ruling forces. In our analysis, we take such an approach one step further and observe the way in which this trend tends to be reduced in jurisdictions with limited political importance. In the next sections, we will use the Portuguese case to address a gap in the literature.

\section{The pork-barrel and irrelevance effects on a model for describing PIDDAC distributions using the Sequential Dictator Games framework}

Until 2010, the distribution of PIDDAC resources was under the discretion of the Portuguese government. Thus, one can reasonably expect that key restrictions were imposed on these expenditures. The first restriction was that the expenditures had to be 
voted on or approved by the Portuguese parliament before being included in a table of the Budget Report (discussed annually). The second restriction was that the expenditures had to be justified responses to specific capital needs in given Portuguese areas or municipalities. The third restriction was that the PIDDAC distribution values were expected to motivate appeals from the municipalities receiving the smallest values and generate erosion of the popularity of the Government and supporting political forces. However, in contrast to the Portuguese Local Finances Law (see Mourao, 2011 for an example), the regulation concerning PIDDAC allows a larger and more discretionary role for the government to favor specific areas and lobbies that truly need help.

Using the Sequential Dictator Games framework, we model the effects of the porkbarrel behavior of the Portuguese government in the context of distributing PIDDAC resources to different municipalities.

As a Dictator Game, a player (e.g., a government) decides how to divide a commodity or an amount of money with a co-player (in this case, a municipality). Whereas a Dictator Game is typically a unique round game, a Sequential Dictator Game allows the opportunity of "revenge/retribution" during a second round. The co-player receives the same amount of money given to the first Dictator and makes an independent decision on a second distribution of resources between the two players. Diekmann (2004) provides a discussion of these two-round Sequential Dictator Games, though the game can be extended to involve an infinite number of moves. Sequential Dictator Games are especially appropriate for Public Economics for three main reasons. First, Sequential Dictator Games are especially able to refresh the study of political cycles reflecting the alternating dominance of parliamentary systems by Left and Right parties. Second, and based on Diekmann (2004)'s analysis, a player in a Sequential Dictator Game is unlikely to offer the same amount that he/she received from the other player during the previous round. These unique dynamics in the Sequential Dictator Games allow us to study the evolution of the expected payoffs. By observing the evolution of the expected payoffs, we can analyze the likelihood for a player to collaborate or to harm the other player. 
However, in our model, we also want to study the extent to which being ruled by the same party that rules the government can benefit a given Portuguese municipality. Based on the pork-barrel literature (Olson, 1965; Ferejohn, 1974; Drazen, 2002), we predict the presence of such benefits. In other words, larger amounts of PIDDAC resources may be distributed to municipalities ruled by the same party that rules the Portuguese government. However, this pork-barrel effect may be limited or offset by the political irrelevance of the potential recipient. As discussed in the next sections, it is common for recipients with a low political importance to receive smaller amounts. Thus, even for municipalities ruled by the same party that rules the government, the expected PIDDAC distribution amounts can be diminished by the low political importance of the municipality. These dynamics have been taken into account in our model.

\subsection{The pork-barrel and the irrelevance effects}

The pork-barrel literature has a long tradition in the fields of public economics and public finances. Following the seminal work of Olson (1965) and Ferejohn (1974), this literature has attracted extensive attention. The two main reasons behind this interest can be summarized in two conceptual expressions (Drazen, 2002): "common sense" and “inefficiency costs". First, as Bratsis (2003) and Groot (2000) argue, it is not difficult to find classic scholars (such as Plato or Solon) who accused rulers of favoring those who supported the established regime in the form of land tenures, tax benefits, the assignment of political positions, and increases in personal wealth. Even among democratic regimes, the common sense perspective (reinforced by the press and the opposition forces) supports the claim that a party ruling a given area tends to favor political agents who support the incumbency or sub-areas with a high concentration of supporters.

Second, following Felton (2006)'s suggestion that pork-barrel distributions are inefficient, several researchers (Weingast, 1984, or Weingast, Shepsle and Johnsen, 1981) have attempted to compute such inefficiency costs. Considering that the ruling 
power manages the public resources that are funded by the general public, it becomes relevant to clarify any costs due to inefficiency associated with the concentration of benefits on particular agents. To make effective analysis possible, the first step is to identify the determinants of pork-barrel behavior (Johnston, 1983).

Hoare (1983) and Drazen (2002) have reviewed the models that discuss or analyze pork-barrel actions. The very first models (Olson, 1965; Ferejohn, 1974) assume that politicians elected by certain jurisdictions seek to obtain an initial proportion of the federal grants to impress the electors and lobbyists in their jurisdiction. These politicians are motivated by the higher probability of being re-elected if they receive significant grants from the centralized government.

The more recent models (Lancaster and Patterson, 1990; McMenemy, 2001; Cadot, Röller and Stephan, 2006; or DeBacker, 2011) build in an additional key feature, which helps us to examine the costs of concentrating public benefits in specific areas by computing the inefficiency costs of pork-barrel actions.

However, there have been other perspectives and insights on this theme. For example, Cox and McCubbins (1986) argue that because public investment is a very visible and expensive outlay, incumbents tend to adopt a risk-aversion attitude and favor the projects and areas with the lowest electoral uncertainty, that is, the areas that support the incumbent party or are ruled by the same party ruling the federal administration. From a different perspective, Dixit and Londgren (1998) argue that governments will favor the jurisdictions that are politically most uncertain because the most politically stable areas tend to be electorally rigid (i.e., clearly favoring either the incumbent or the opposition).

In contrast to the supply-side focus used by Cox and McCubbins (1986) and Dixit and Londgren (1998), Drazen (2002) proposes that there are reasons on the demand side that may explain the existence of pork-barrel actions. For instance, most electors and taxpayers will opt for a project whose benefits focus on their residential area but whose costs are shared with other jurisdictions. According to Weingast $(1981,1984)$ and Weingast, Shepsle and Johnsen (1981), electors tend to overestimate the benefits of these projects by assuming that huge local investments are correlated with the creation of a large number of jobs and a large stimulus of local income (Baron, 1991). As a result, in the next election, electors will vote for the political party that promises funds for their local investments. 
In summary, governments tend to favor the regions with greater political affinity to the majority party, that is, the areas ruled by the same party that rules the government itself. The electors who want to benefit from federal funding will likely recognize and vote for candidates of the "friendlier" party.

Although the term 'pork-barrel' is widely disseminated within North American and northern European literature ${ }^{3}$, it appeared only recently in the southern European economics discourse. Veiga and Veiga (2011) analyzed how simultaneity (i.e., the same party ruling both the Portuguese government and a given municipality) might increase the amount of capital and investment transfers given to that municipality. These authors concluded that Portuguese intergovernmental fiscal transfers indicate a clear pork-barrel effect. Another southern European reference is Limosani and Navarra (2001). Taking the case of Italy, the authors found evidence of a strategic cooperative relationship between local policymakers and candidates running in national elections. The conclusion is clear: "In pre-election periods, national representatives try to obtain investment expenditures for specific projects to be spent in their electoral districts with the help of 'friendly' local governments in order to increase their popular consent." Costa-i-Font, Rodriguez-Oreggia and Lunapla (2003) co-authored a discussion of porkbarrel effects in a context outside North America and northern Europe. Focusing on Mexican electoral periods, the authors concluded that a positive relationship exists between the regional allocation of public investment and support for the central ruling party. In a second study of the situation in Mexico, Costa-i-Font and Rodriguez-Oreggia (2006) concluded that the Mexican federal government (dominated by the single party Partido Revolucionário Institucional between 1929-2000) made little difference to the way in which public investment was allocated until the 1990s. After the 1990s, changes were made to the way in which the Mexican federal government distributed public investment, leading to the weakening of previous 'path dependency'.

However, the early literature (especially Johnston, 1983 and Hoare, 1985) ${ }^{4}$ also highlights the significant restrictions that may be observed in the two-way relationship

\footnotetext{
${ }^{3}$ See Hoare (1983) or Mourao and Cunha (2012).

${ }^{4}$ The literature on the Economics of Giving (Ruffle, 1999; Mitrut and Nordblom, 2010) also discusses this issue. For example, at a street collection, if a giver does not believe that the requested contribution will
} 
between a giver (the pork-barrel creator) and a recipient. These restrictions can explain why certain givers donate different amounts to recipient agents who exhibit the same characteristics. The same phenomenon happens when a federal government has doubts about the efficiency or the relevancy of its grants attributed to a certain region. In such cases, the government responds by lowering the value of the grant attributed to that inefficient (or less important) decentralized space. Thus, the government tends to favor more efficient (or visible) regions (Hoare, 1985). Following Segal and Whinston (2000) and Khemani (2007), we refer to this effect as the 'irrelevance effect'.

As a result of this irrelevance effect, a municipality may receive a reduced share of its expected funding for reasons unrelated to political orientation (Hoare, 1985).

\subsection{Our Sequential Dictator Game model}

Based on Queller (1985) and Diekman (2004) $)^{5}$, we model the expected payoff of donation $\left(\right.$ payoff $_{i t}$ ) for a given municipality $i$ at a given year $t$ based on the pork-barrel effect $p_{i t}$ and on the level of irrelevance $\left(u_{i t}\right)$.

That is, for each ordered pair $(a, b)=\{$ Right, Left $\}$ in which $a$ (the first coordinate) identifies the party ruling the government and $b$ (the second coordinate) identifies the party ruling the municipality, the expected payoff is given by

$$
\operatorname{payoff}_{i t}^{(a, b)}=f\left(p_{i t}^{(a, b)} ; u_{i t}^{(a, b)}\right) .
$$

Therefore, we can linearize the payoff function as

\footnotetext{
go to support a socially approved program (such as helping orphans), then this giver tends to reduce the value of the contribution (Zak, 2010). However, the giver may simply not approach the recipient due to the excessive modesty of the recipient (for a discussion of search costs, see Kaplan and Ruffle, 2009).

${ }^{5}$ Please see the Appendix for an extended explanation.
} 
payoff $_{i t}^{(a, b)}=K^{(a, b)}+p_{i t}^{(a, b)}-u_{i t}^{(a, b)}+v_{i t}^{(a, b)}$

(eq. 2)

According to the previous equation (equation 2), and conditioned on each ordered pair $(a, b)$, the payoff expected by a given municipality $i$ for a given year $t$ depends on the constant net value $\mathrm{K}$, the pork-barrel effect $p$, the irrelevance measure $\mathrm{u}_{\mathrm{i}}$, and a set of random variables $\left(v_{i t}\right)$ following the typical assumption of normally distributed error terms [iid $\sim \mathrm{N}\left(0, \sigma_{v}^{2}\right)$ ]. We also assume that $u_{i t}$ depends on a set of non-negative ${ }^{6}$ variables. As established by the literature, these variables are assumed to be independently distributed as truncations at zero of the $\mathrm{N}\left(\mathrm{m}_{\mathrm{it}}, \sigma_{u}^{2}\right)$ distribution. The mean of this distribution is a function of vector $z$ of the variables influencing the social and economic importance of the municipality ${ }^{7}$ (i.e., the national proportion of parishes at each municipality ${ }^{8}$, the population density ${ }^{9}$, and the proportion of elderly people ${ }^{10}$ ). To control for the opportunistic trends ${ }^{11}$ observed at electoral moments (Aidt, Veiga and Veiga, 2011), dummy variables coding for electoral years are included in vector $z$.

\footnotetext{
${ }^{6}$ See Battese and Corra (1977) or Battese and Coelli (1995).

${ }^{7}$ To test the importance of the municipality, we constructed a set of related explanatory variables based on Johnston (1983), Hoare (1985), and Khemani (2007).

${ }^{8}$ Each Portuguese municipality contains administrative sub-units called 'freguesias' or parishes. Each parish has a 'mayor', the Presidente da Junta de Freguesia, elected for 4 years jointly with the municipal Mayor. Each Presidente da Junta de Freguesia automatically receives a seat in the municipal assembly. Therefore, municipalities with a larger number of parishes may be subjected to greater pork-barrel effects. To evaluate this trend, we use the national proportion of the number of parishes at each municipality. GIven a municipality with $3 \%$ of the Portuguese parishes and another municipality with $5 \%$ of the Portuguese parishes, we expect the municipality with $5 \%$ of the parishes to receive more attention from the Portuguese Government

${ }^{9}$ The population density is given by the number of individuals residing in each Portuguese municipality divided by the area of that municipality (i.e., number of people per square kilometers).

${ }^{10}$ In our case, we consider the proportion of people living in each municipality who are older than 65 years of age.

${ }^{11}$ We also tried to control the political competition in each municipality using a common indicator: the share of votes received by the most voted-for party on the share of the remaining votes at the last
} 
$m_{i t}^{(a, b)}=z_{i t}^{(a, b)} * \delta^{(a, b)}+\varepsilon_{i t}^{(a, b)}$

where $\delta$ is a vector of parameters to be estimated and $\varepsilon_{i t}$ will be estimated under the iid assumptions.

As previously stated, the pork-barrel effect $p$ depends on the proportion of mandates in the municipal executive power (i.e., the proportion of aldermen) and the proportion of seats in the municipal legislative institution (i.e., at the municipal assembly).

Following Battese and Corra (1977), Equations 2 and 3 constitute a two-equation system.

The simultaneous maximum likelihood estimation of this system is expressed in terms of the variance parameters

$\sigma^{2}=\sigma_{v}^{2}+\sigma_{u}^{2}$ and $\gamma=\frac{\sigma_{u}^{2}}{\sigma_{u}^{2}+\sigma_{v}^{2}}$ to provide asymptotically efficient estimates. Therefore, a test of the significance of the parameter $\gamma$ is a test of the significance of the specification of the system (Battese and Corra, 1977).

municipal election (Niskanen, 1998). The simplest rationale notices that the Portuguese government may favour municipalities where a slight shift in public opinion can lead to a change of local government. However, we were not able to reject the null hypothesis of statistical non-significance of the estimated coefficients for this indicator, for each of the sub-samples or for the entire sample. Therefore, for parsimony, we did not include those estimates in these tables. The complete results are available on request. 
Following Battese and Corra (1977)'s demonstration, our irrelevance measure for a given municipality $i$ is computed as

irrelevance $_{i}=e^{\left(-u_{i}\right)}=e^{\left(-z_{i t}^{*} \delta-\varepsilon_{i t}\right)}$.

\section{4 - Empirical model, data and results}

\section{1- Empirical model}

The goal of this work is to test the presence of pork-barrel effects in PIDDAC distributions. As argued above, these effects can be attenuated by 'irrelevance'. Thus, we specify our model as follows for each ordered pair $(a, b)=\{$ Right; Left $\}$, considering that the expected payoff for a given municipality $i$ is identified with the received $(\log )$ value of the PIDDAC amounts at year $\mathrm{t}$ :

$$
\begin{array}{ll}
\text { lpiddac }_{i t}= & K_{0}+\alpha_{1}^{*} \text { mandates }_{i t}+\alpha_{2} * \text { seats }_{i t}+v_{i t}-u_{i t} \\
u_{i t}= & \delta_{1} * \text { parishes }_{i t}+\delta_{2} * \text { density }_{i t}+\delta_{3} * \text { elder }_{i t}+\delta_{4} * \text { election }_{i t}+\varepsilon_{i t}
\end{array}
$$

We consider the following measures of the pork-barrel effect as independent variables for the first equation of the system: the (log) number of mandates in the municipal executive power of municipality $i$ obtained by the ruling party of the Portuguese government and the (log) number of seats in a given municipal assembly obtained by the same ruling party, for the given year $t$. As previously introduced, $v_{i t}$ follows the typical assumption of normally distributed error terms. To account for the irrelevance effect associated with each municipality, we model $u_{i t}$ as a function of several 
observable explanatory variables (i.e., the log of the national percentage of parishes under the administrative border of the municipality; the log of population density; the $\log$ of the proportion of the population over 65 years of age; and electoral years).

\section{2 - The Data}

The data sources for our variables are shown in table 2 .

[INSERT HERE TABLE 2]

Despite our attempts to obtain PIDDAC data from the early 1980s, the precise values are unavailable in the reports for two reasons. The first is a regulatory reason. As previously noted, it was only after 1991 that the PIDDAC tables were required to present values by municipality. Therefore, decentralized values were only available after 1991. The second reason concerns data availability. Despite repeated requests, the Portuguese General Directorate of the Budget did not make the Portuguese Public Budget Reports and their tables available until 1997.

This empirical analysis was performed using panel data. Table 3 reports the descriptive statistics for the following variables: the (log of) PIDDAC amounts; the (log of the number of mandates in the municipal executive power of municipality $i$ obtained by the party that rules the Portuguese government; and the (log of) the number of seats in the municipal assembly obtained by the party that rules the Portuguese government. Table 3 also reports the following variables: the (log of) the number of the national percentage of parishes under the administrative border of the municipality; the (log of) the population density; the (log of) the proportion of the population aged over 65 years; and electoral years. We divided these descriptive statistics into the following four groups in relation to the four ordered pairs given by $(a, b)=\{$ Right; Left $\}$ : 
i) Municipalities ruled by Left ${ }^{12}$ parties under a Left government;

ii) Municipalities ruled by Left parties under a Right government;

iii) Municipalities ruled by Right parties under a Left government; and

iv) Municipalities ruled by Right parties under a Right government.

[Insert here Table 3]

In particular, following Limosani and Navarra (2001), we observed that municipalities ruled by the same party that ruled the Portuguese government tended to have a larger number of local mandates or seats belonging to that party than municipalities lacking similar simultaneity. However, Chi-squared analyses precluded us from making the same conclusion regarding the PIDDAC distribution using these descriptive statistics. Following Battese and Coelli (1995), this fact supports the estimation of our system of equations based on maximum likelihood (over other common estimators, such as GLS fixed-effects or the Generalized Method of Moments).

\section{3 - Results}

Table 4 displays the results of the estimations of our system using the specifications presented in Battese and Coelli (1995). Given that the null hypothesis (that the non-

\footnotetext{
${ }^{12}$ The following Portuguese political movements are considered to be Left parties: PS (Partido Socialista Português); CDU (Coligação Democrática Unitária, a coalition whose major party is the Portuguese Communist Party); and BE (Bloco de Esquerda, a coalition of heterogeneous leftist movements). The following are considered to be Right parties: PPD-PSD (Partido Social Democrata, the Social Democratic party) and CDS-PP (a Democratic Christian party). For the few municipalities ruled by Independent Movements (groups of citizens who were not members of any party), we considered them as belonging to the wing opposite to the second most voted-for party for the municipal council (for example, if the second most voted-for party belonged to the Left wing, then the winning Independent Movement was, in this work, identified as belonging to the Right Wing).
} 
random component of the residual, parameter $\gamma$ is not significant) can be rejected in all specifications, we can conclude that our model specifications (i.e., the system of equations) are acceptable for analyzing the pork-barrel effect in the context of Portuguese PIDDAC distributions.

[Insert here Table 4]

In Table 4, the results of the estimations are reported in relation to the four divisions of our Matrix $2^{13}$. In all columns, the results indicate that our system of equations performs relatively well, with high statistical significance (significance levels of 1\%) found for the estimates of the parameter Gamma $(\gamma)$ across all of our specifications.

Let us discuss our first equation in terms of the variables "Number of seats" and "Number of local mandates of the same party that rules the government". First, the estimated coefficient for "number of seats" is only significant for municipalities ruled by a majority of Right parties under a Right government ( $4^{\text {th }}$ column), although Right governments are also sensitive to municipalities ruled by Left parties that exhibit relatively large numbers of Right aldermen. In contrast, the PIDDAC transfers made by

\footnotetext{
${ }^{13}$ For comparison, we also computed an estimation based on Battese and Coelli (1995)'s specification based on all the observations of the sample (collapsing across the four divisions), yielding the following result:

$$
\begin{aligned}
& \text { piddac }_{i t}=\underset{(0.866)}{13.507}+\underset{(0.145)}{0.167 * \text { mandates }_{i t}}+\underset{(0.099)}{0.747} * \text { seats }_{i t}-\left[-\underset{(2.569)}{11.674} * \% \text { parishes }_{i t}-\underset{(0.097)}{0.636} \text { density }_{i t}-\right. \\
& \left.\underset{(0.432)}{0.912} * \%{\text { pop } 65_{i t}}_{(0.070)}^{0.218} * \text { election }_{i t}-\underset{(0.077)}{0.592} * \text { mandates }_{i t}^{0} * \text { Right }_{-} \text {at_Govntm }\right)+ \\
& \left.\left.+\underset{(0.116)}{0.176} * \text { mandates }_{i t} * \text { Right }_{-} a t_{-} \text {Municipality }\right)\right]+v_{i t}+\varepsilon_{i t}
\end{aligned}
$$

With these estimates, we can confirm the statistical significance of most of the coefficients, especially for the number of seats, the national percentage of parishes in each municipality, the population density and the electoral years. In this specification, we have also confirmed that the two interaction variables (the interaction of the number of mandates and the dummy 'Right at Government' and the interaction of the number of mandates and the dummy 'Right at the Municipality') are statistically significant, supporting the decision to divide the sample into four groups according to the ruling party at the Government and Municipality levels.
} 
Left governments are not as sensitive to the assembly composition of Right municipalities. Therefore, we can conclude that there is evidence for pork-barrel practices in the context of PIDDAC distributions. In other words, the Portuguese government increases the amount of PIDDAC resources allocated to each municipality given a high number of mandates (aldermen) who share the same political affiliation as the National Executive.

Now, let us consider the second equation (the estimation of $u_{i t}$ ), which takes into account the irrelevance effect. In this equation, a negative coefficient means that higher values in a given variable are associated with smaller values of $u_{i t}$, i.e., with higher political importance (Battese and Corra, 1977; Battese and Coelli, 1995) and (based on the current system specifications) higher values of allocated PIDDAC ${ }^{14}$. Therefore, a higher percentage of parishes concentrated in a given municipality is associated with a lower irrelevance effect and a higher percentage of PIDDAC resources allocated to the municipality. Note that the latter finding is true across all cases with the exception of Left municipalities under Left governments. A closer look reveals that for municipalities with higher population densities, the irrelevance effect tends to be relaxed, and the PIDDAC transfers increased around legislative elections (Aidt, Veiga and Veiga, 2011). Finally, a special comment needs to be made for the "Left Municipalities/Left Government cases" (first column at Table 4): for these cases, only legislative elections act on or modify the irrelevance effect.

Next, we construct Matrix 3 on the basis of Matrix 2 as follows:

[INSERT HERE MATRIX 3]

\footnotetext{
${ }^{14}$ Following equation 4 based on Battese and Corra (1977), we are able to rank the Portuguese municipalities according to their level of 'irrelevance' in terms of the PIDDAC distribution. The 10 most irrelevant Portuguese municipalities (based on average values for the given time period) are as follows: Camara de Lobos, Santa Cruz, Machico, São Pedro do Sul, Mangualde, Alvaiázere, Cadaval, Porto de Mós, Vila Pouca de Aguiar, and Arcos de Veldevez. The full set of rankings are available on request.
} 
As shown in Matrix 3, other issues arise. First, if we use the same values for mandates and seats across different municipalities, the PIDDAC distributions tend to reach the most significant values in the cases involving Right municipalities under Right governments. Interestingly, with regard to the irrelevance effect (whose estimates are presented in brackets), Right municipalities with higher values for parish numbers and population density and during electoral years tend to receive more PIDDAC funds from the government, regardless of the political affiliation of the national executive power. Finally, we consider the influence of electoral cycles. Following Aidt, Veiga and Veiga (2011), we found that the generosity of the government increased during electoral years, even in the case of discretionary expenditures such as the PIDDAC. Specifically, a Portuguese municipality can expect higher PIDDAC distributions during electoral years if its ruling party shares a political affiliation with the party ruling the Portuguese government. If not, then electoral years tend to promote an increase in PIDDAC distributions when the Portuguese government is ruled by Left parties.

\section{Conclusion}

In this work, we analyzed the distribution of the Portuguese program of decentralized public investments (PIDDAC) to Portuguese municipalities since 1997. In particular, we considered the presence of pork-barrel effects and the way in which these effects are mitigated given the different levels of political relevance characterizing each municipality.

Although the literature on pork-barrel effects has documented several cases in which ruling parties have shown a clear preference for areas in which the supporters of the incumbency are concentrated, this is the first research project to discuss PIDDAC distributions and test for the presence of pork-barrel and irrelevance effects.

Our theoretical model is developed based on a Sequential Dictator Games framework. In discussing discretionary expenditures, we noted the benefits of modeling governmental behavior as similar to the "first player" of the Dictator Games, who 
decides on the amount given to the recipient player. Moreover, a sequential framework is appropriate for discussions and analyses on public economics by enabling us to model the alternation between political parties in the incumbency.

We considered the four possible scenarios based on the combination of Left or Right governments that distribute decentralized investment transfers to municipalities ruled by Left or Right parties. The results revealed the presence of pork-barrel effects and the existence of irrelevance effects.

Regarding pork-barrel effects, our observations revealed that the Portuguese government tended to favor the municipalities with a larger number of elected aldermen ('vereadores') sharing a political affiliation with the national executive power. Although we also verified the municipal assemblies' composition, we did not find statistically significant results regarding this dimension.

Regarding irrelevance effects, our findings showed that low-density municipalities with fewer parishes tended to be the most neglected municipalities in terms of PIDDAC distributions. We also found evidence for the attenuation of these irrelevance effects during legislative electoral years.

This work opens up promising routes for future research. First, we would like to expand our database to include all the years since the release of the first Public Budget Report detailing PIDDAC distributions for municipalities. Second, we intend to test this framework while taking into account all decentralized transfers (i.e., of the current capital expenditures) that the Portuguese government distributes to the municipalities. Finally, this framework, which specifically considers pork-barrel effects controlled by the irrelevance level of the recipient, can be used to test other cases of decentralized grants, including European Union (EU) transfers to the its member states.

Acknowledgements: The author would like to acknowledge considerable support from Mourao and Cunha (2012), who made their database available.

\section{References:}


Aidt, T., Veiga, F. and L. Veiga (2011); "Election results and opportunistic policies: a new test of the rational political business cycle model"; Public Choice; 148, 1-2; $21-44$

Baron, D. (1991), "Majoritarian Incentives, Pork Barrel Programs, and Procedural Control”, American Journal of Political Science, 35, 57-90

Battese, G. and G. Corra (1977), "Estimation of a Production Frontier Model: with application to the pastoral zone of eastern Australia", Australian Journal of Agricultural Economics, 21, 169-179.

Battese, G. and T. Coelli (1995), "A model for technical inefficiency effects in a stochastic frontier production function for panel data", Empirical Economics, 20, 325-332.

Bratsis, P. (2003); "Corrupt Compared to What? Greece, capitalist interests, and the specular purity of the State"; Discussion Paper $n .8$ - The Hellenic Observatory/ The European Institute - London School of Economics and Political Science

Cadot, O., Röller, L. and A. Stephan (2006); "Contribution to productivity of pork barrel - The two faces of infrastructure investment"; Journal of Public Economics, 90, 6-7; 1133-1153

Costa-i-Font, J., Rodriguez-Oreggia, E., and D. Lunapla (2003); "Political competition and pork-barrel politics in the allocation of Public Investment in Mexico"; Public Choice, 116, 1-2; 185-204

Costa-i-Font, J., and E. Rodriguez-Oreggia (2006); "Path dependency and the allocation of public investment in Mexico"; Environment and Planning C: Government and Policy; 24 (2); 297-311

Cox, G. and M. McCubbins (1986); "Electoral politics as a redistributive game”; Journal of Politics 48(2); 370-389.

De Fontenay, C., Gans, J., and V. Groves (2010). "Exclusivity, competition and the irrelevance of internal investment" International Journal of Industrial Organization, 28; 336-340.

DeBacker, J. (2011); “The price of pork: The seniority trap in the U.S. House"; Journal of Public Economics, 95 (1-2), p.63-78.

DelRossi, A. and R. Inman (1999); "Changing the price of pork: the impact of local cost sharing on legislators' demand for redistributive public goods"; Journal of Public Economics; 71, 2; 247-273

DGAA, Direcção-Geral das Autarquias Locais (2012); "Legislação"; Available site: http://www.portalautarquico.pt/portalautarquico/Home.aspx

Diekmann, A. (2004); "The power of reciprocity - fairness, reciprocity, and stakes in Variants of the Dictator Game"; Journal of Conflict Resolution; 48, 4 ; 487-505 
Dixit, A. and J. Londregan (1998), "Fiscal federalism and redistributive politics", Journal of Public Economics 68, 295-303.

Drazen, A. (2000), "Political economy in Macroeconomics", Princeton University Press, Princeton

Felton, R. (2006); “Poker and the pork barrel”; Metal Powder Report 61 (4), p.3

Ferejohn, John A. 1974. "Pork Barrel Politics: Rivers and Harbors Legislation, 19471968”, Stanford: Stanford University Press.

Fernandes, M. (1984). PIDDAC/84; Ministério da Educação - Gabinete de Estudos e Planeamento; Lisboa

Groot, L. (2000); "Roger Caillois, Games of Chance and the Superstar"; Diogenes, 48,$2 ; 33-42$

Hoare, A. (1983); Pork-barrelling in Britain: a review; Environment and Planning C; 1; $413-438$

Johnston, R. (1983), "The feedback component of the pork barrel: tests using the results of the 1983 General Election in Britain"; Environment and Planning A ;15; $1691-1696$

Kaplan, T. and B. Ruffle (2009); "In search of welfare-improving gifts"; European Economic Review, Volume 53, Issue 4, 445-460

Khemani, S. (2007) "Can Information Campaigns Overcome Political Obstacles to Serving the Poor?" In Devarajan, Shantayanan and Ingrid Widlund (eds) The Politics of Service Delivery in Democracies. Better Access for the Poor, EGDI Secretariat Edita, Stockholm

Lancaster, T. and W. Patterson (1990), “Comparative Pork Barrel Politics: Perceptions from the West German Bundestag”, Comparative Political Studies; 22; 458-477

Leigh, A. And C. Neill (2011); "Can national infrastructure spending reduce local unemployment? Evidence from an Australian roads program"; Economics Letters; 113 (2); 150-153

Levy, M. (2012); "Co-monotonicity: Toward a utility function capturing envy"; Economics Letters; 114, 1; 16-19

Limosani, M. and P. Navarra (2001); "Local pork-barrel politics in national pre-election dates: the case of Italy"; Public Choice; 106, 3-4; 317-326

McMenemy, J. "The Language of Canadian Politics: A Guide to Important Terms and Concepts", 3rd edition. 2001. Wilfrid Laurier University Press;.224-225

Mitrut, A. and K. Nordblom (2010); "Social norms and gift behavior: Theory and Evidence from Romania"; European Economic Review; 54, 8; 998-1015

Mourao, P. (2011); "Distribution matters - the case of Portuguese municipalities"; 9 " Workshop APDR 'Descentralização Financeira e Desorçamentação'; Universidade do Minho 
Mourao, P. and E. Cunha (2012); "Políticas Pork-Barrel: um estudo sobre o caso português do PIDDAC"; Econômica; 13 (1); p.73-93

Niskanen, W. (1998), “A Vote for Perot was a Vote for the Status Quo.” Cato Journal, $18,(1) ; 85-91$.

Oliveira Martins, G., Oliveira Martins, G. e M. Oliveira Martins (2007); A Lei do Enquadramento Orçamental - Anotada e Comentada; Almedina, Coimbra

Olson, M., (1965). "The Logic of Collective Action”. Harvard University Press, Cambridge, MA

Queller, D. (1985). "Kinship, reciprocity and synergism in the evolution of social behavior." Nature (London) 318, 366-367.

Ruffle, B. (1999); "Gift giving with emotions"; Journal of Economic Behavior \& Organization; 39, 4; 399-420

Segal, I. and M. Whinston (2000); "Exclusive Contracts and Protection of Investments," RAND Journal of Economics, 31(4); 603-633.

Sperber, D. and D. Wilson (1987). "Précis of Relevance: Communication and Cognition.” Behavioral and Brain Science, 10, 697-754.

Veiga, L. and F. Veiga (2011); "Intergovernmental fiscal transfers as pork barrel"; Public Choice, DOI: 10.1007/s11127-011-9863-2

Weingast, B. Shepsle, K. and C. Johnsen (1981), "The Political Economy of Benefits and Costs: A Neoclassical Approach to Distributive Politics"; Journal of Political Economy, Vol. 89, No. 4 (Aug., 1981), pp. 642-664

Weingast, B. (1981) "Regulation, Reregulation, and Deregulation: The Political Foundations of Agency Clientele Relationships" Law and Contemporary Problems, Vol. 44, No. 1, Managing the Transition to Deregulation (Winter, 1981), pp. 147-177

Weingast, B. (1984) "The Congressional-Bureaucratic System: A Principal Agent Perspective (with applications to the SEC)"; Public Choice, Vol. 44, No. 1, Carnegie Papers on Political Economy, Volume 4: Proceedings of the Carnegie Conference on Political Economy (1984), pp. 147-191

Yus, F. (2006); "Relevance Theory"; in vv.aa., eds, (2006) Encyclopedia of Language and Linguistics; University of Alicante, Alicante.

Zak, P. (2011); "Moral Markets"; Journal of Economic Behavior \& Organization, Volume 77, Issue 2, 212-233

Portuguese legislation:

Portuguese Republic Assembly (1977); “Law 64/77”; Diário da República, 26 August

Portuguese Republic Assembly (1983); "Law 40/83”; Diário da República, 13 December 
Portuguese Republic Assembly (1990); "Law 8/1990"; Diário da República, 20 February

Portuguese Republic Assembly (1991); "Law 6/1991"; Diário da República, 20 February

Portuguese Republic Assembly (2001); “Law 91/2001”; Diário da República; 20 August

Portuguese Republic Assembly (2004); "Law 48/2004"; Diário da República; 24 August

Portuguese Republic Assembly (2011); “Law 22/2011”; Diário da República; 20 May 
APPENDIX - Constructing matrixes of expected payoffs that account for pork-barrel and irrelevance effects

According to our model, there is a benefit $b$ to a municipality when hosting transferred expenditures (e.g., PIDDAC). Leigh and Neill (2011) and Baron (1991) have identified some of these benefits, such as an expected increase in the number of jobs created in local markets and a rise in local aggregate demand. However, there may also be costs associated with the PIDDAC distribution. First, being a public program, PIDDAC has to be funded by public revenues, for which the costs (i.e., more directly charged by the government and indirectly by municipalities) can be identified as a loss of popularity, social claims and growth attrition (Del Rossi and Inman, 1999). Second, there are costs associated with the uneven distribution of this program (Mourao, 2011). Finally, recipient players may charge 'preference costs', such as 'jealousy' costs incurred by the non-recipient 'Joneses'-type players (Levy, 2012). There may also be increased inspection by the donors. We are going to identify the total cost as $c$. For the sake of simplicity, let $K$ be the net benefit to a municipality receiving PIDDAC expenditures, i.e., $K=b-c$.

This benefit is increased by $p$, the pork-barrel effect ${ }^{15}$, which occurs when the same party rules the Portuguese government and a given municipality. Following Veiga and Veiga (2011), $p$ is measured as a function based on the proportion of local executive mandates (in Portuguese 'vereadores') obtained by the party ruling the government or the proportion of seats that this party obtains at each municipal assembly (as suggested by Limosani and Navarra, 2001) ${ }^{16}$.

\footnotetext{
${ }^{15}$ Queller (1985) identifies it as a synergistic effect of the Games Theory models.

${ }^{16}$ In Portugal, the local power is divided into two main branches - the executive power (namely, the Mayor and the aldermen) and the legislative power (namely, the municipal assemblies). The local executive power is assumed by the Mayor ('Presidente da Camara Municipal'), who shares the local executive power with a group of elected people, the aldermen ('vereadores'). The aldermen are elected using the d'Hondt method, which allows the aldermen representing the party that receives the most votes to work with a few of the aldermen belonging to the remaining competitor parties. The number of aldermen is a function of the number of individuals residing in each municipality. The two historically
} 
Based on these assumptions, the expected payoff matrix for this Sequential Dictator Game is as follows:

\section{[INSERT HERE MATRIX 1]}

This matrix means that when a right-wing party rules the Portuguese government, the expected payoff for a municipality ruled by the same right-wing party is $K^{r r}+p^{r r}$, whereas the expected payoff for a municipality ruled by the left-wing party is only $K^{r l}$.

Following Diekmann (2004), the only assumption we make is that these payoffs are different among themselves. In other words, we do not assume a symmetry of the donation, or $K^{r r}+p^{r r}=K^{l l}+p^{l l}$. In fact, there is no objective reason to expect the same political and economic scenario to occur when the right-wing party rules the government in a situation previously modeled based on a left-wing government. There are various reasons behind this assumption, including different phases of national and/or international economic cycles, changes in exogenous dimensions (e.g., financial markets) or new restrictions imposed by national public finances. However, we also assume that the expected payoff for a municipality ruled by the same party that rules the government will always be higher than the expected payoff for a municipality belonging to the opposition. In this case, we have $\left\{K^{r r}+p^{r r} ; K^{l l}+p^{l l}\right\}>\left\{K^{l r} ; K^{r l}\right\}$.

most important municipalities, Lisbon and Oporto, have 16 and 12 aldermen, respectively, whereas most of the remaining municipalities have fewer aldermen, depending on the number of residents per municipality (DGAA, 2012). The number of seats at each municipal assembly is constituted by the maximum value between two figures: the first figure is equal to three times the number of aldermen ('vereadores') and the second magnitude is equal to twice the number of parishes in the municipality plus one. To illustrate, the number of seats in a given municipality with 4 aldermen and 10 parishes is the maximum number between $12(3 \times 4)$ and $21(2 \times 10+1)$. Consequently, the number of seats at that municipal assembly is 21 . Following the $d^{\prime}$ Hondt method, the number of seats at each municipal assembly is divided by the number of the political forces. 
However, even for a municipality ruled by a given party that simultaneously rules the government, there may be specific sources of irrelevance that offset or control the porkbarrel effect per se. For example, a Right government will give less importance to a municipality in which all 3 aldermen belong to the Right party than a municipality controlled by the Left but with 6 aldermen belonging to Right. Therefore, high levels of irrelevance charged to a municipality reduce the amount that it can receive via PIDDAC, even from a government ruled by the same party. Therefore, the previous matrix generates a new one that corrects for the previous payoffs with the irrelevance effect specific to the given municipality.

\section{[INSERT HERE MATRIX 2]}

In Matrix 2, we impose no other assumption but an update of the previous inequality assumption: $\left\{K^{r r}+p^{r r}-u^{r r} ; K^{l l}+p^{l l}-u^{l l}\right\}>\left\{K^{l r}-u^{l r} ; K^{r l}-u^{r l}\right\}$. 
TABLES and FIGURES 
Table 1 - Percentages of PIDDAC distributed by Portuguese districts (1997-2009)

\begin{tabular}{|c|r|r|r|r|r|r|}
\hline & $\begin{array}{c}\text { Average } \\
\text { PIDDAC } \\
(\%)\end{array}$ & $\begin{array}{c}\text { Average } \\
\text { Electors }(\%)\end{array}$ & $\begin{array}{c}\text { Average } \\
\text { PIDDAC } \\
(\%)\end{array}$ & $\begin{array}{c}\text { Average } \\
\text { Electors }(\%)\end{array}$ & $\begin{array}{r}\text { Average } \\
\text { PIDDAC } \\
(\%)\end{array}$ & $\begin{array}{c}\text { Average } \\
\text { Electors }(\%)\end{array}$ \\
\hline Distritcts & $(1997-2001)$ & $(1997-2001)$ & $\begin{array}{c}(2002- \\
2005)\end{array}$ & $\begin{array}{c}(2002- \\
2005)\end{array}$ & $\begin{array}{c}(2006- \\
2009)\end{array}$ & $\begin{array}{c}(2006- \\
2009)\end{array}$ \\
\hline aveiro & $6.22 \%$ & $7.04 \%$ & $5.82 \%$ & $6.91 \%$ & $5.48 \%$ & $6.91 \%$ \\
\hline beja & $3.24 \%$ & $1.56 \%$ & $3.12 \%$ & $1.45 \%$ & $3.75 \%$ & $1.45 \%$ \\
\hline braga & $5.45 \%$ & $8.88 \%$ & $5.28 \%$ & $8.12 \%$ & $3.79 \%$ & $8.12 \%$ \\
\hline bragança & $2.24 \%$ & $1.41 \%$ & $2.23 \%$ & $1.35 \%$ & $2.90 \%$ & $1.35 \%$ \\
\hline castelo branco & $2.57 \%$ & $2.00 \%$ & $2.43 \%$ & $1.88 \%$ & $3.08 \%$ & $1.88 \%$ \\
\hline coimbra & $4.64 \%$ & $4.36 \%$ & $4.22 \%$ & $4.10 \%$ & $6.23 \%$ & $4.10 \%$ \\
\hline évora & $2.64 \%$ & $1.71 \%$ & $2.62 \%$ & $1.60 \%$ & $3.44 \%$ & $1.60 \%$ \\
\hline faro & $6.13 \%$ & $4.39 \%$ & $5.59 \%$ & $4.00 \%$ & $5.09 \%$ & $4.00 \%$ \\
\hline guarda & $1.93 \%$ & $1.64 \%$ & $1.88 \%$ & $1.63 \%$ & $2.78 \%$ & $1.63 \%$ \\
\hline leiria & $3.05 \%$ & $4.93 \%$ & $2.95 \%$ & $4.51 \%$ & $2.57 \%$ & $4.51 \%$ \\
\hline lisboa & $22.04 \%$ & $22.90 \%$ & $21.21 \%$ & $21.01 \%$ & $23.36 \%$ & $21.01 \%$ \\
\hline portalegre & $1.82 \%$ & $1.18 \%$ & $1.70 \%$ & $1.12 \%$ & $2.07 \%$ & $1.12 \%$ \\
\hline porto & $22.59 \%$ & $17.29 \%$ & $21.77 \%$ & $17.15 \%$ & $16.18 \%$ & $17.15 \%$ \\
\hline santarém & $4.67 \%$ & $4.41 \%$ & $4.37 \%$ & $4.39 \%$ & $3.71 \%$ & $4.39 \%$ \\
\hline setúbal & $6.72 \%$ & $8.66 \%$ & $6.70 \%$ & $8.01 \%$ & $6.50 \%$ & $8.01 \%$ \\
\hline viana do castelo & $2.01 \%$ & $2.55 \%$ & $1.83 \%$ & $2.37 \%$ & $1.68 \%$ & $2.37 \%$ \\
\hline vila real & $2.16 \%$ & $2.08 \%$ & $2.10 \%$ & $2.06 \%$ & $2.87 \%$ & $2.06 \%$ \\
\hline viseu & $2.91 \%$ & $3.89 \%$ & $2.84 \%$ & $3.72 \%$ & $2.90 \%$ & $3.72 \%$ \\
\hline ra açores & $1.00 \%$ & $2.42 \%$ & $0.92 \%$ & $2.30 \%$ & $0.97 \%$ & $2.30 \%$ \\
\hline ra madeira & $0.46 \%$ & $2.53 \%$ & $0.42 \%$ & $2.32 \%$ & $0.64 \%$ & $2.32 \%$ \\
\hline Sourc $\%$ & & & & \\
\hline
\end{tabular}

Source: Own calculations on DGO (1997-2009) \& INE (1997-2009)

Figure 1- Gini Index for PIDDAC distribution for Portuguese municipalities (1997-2009) 


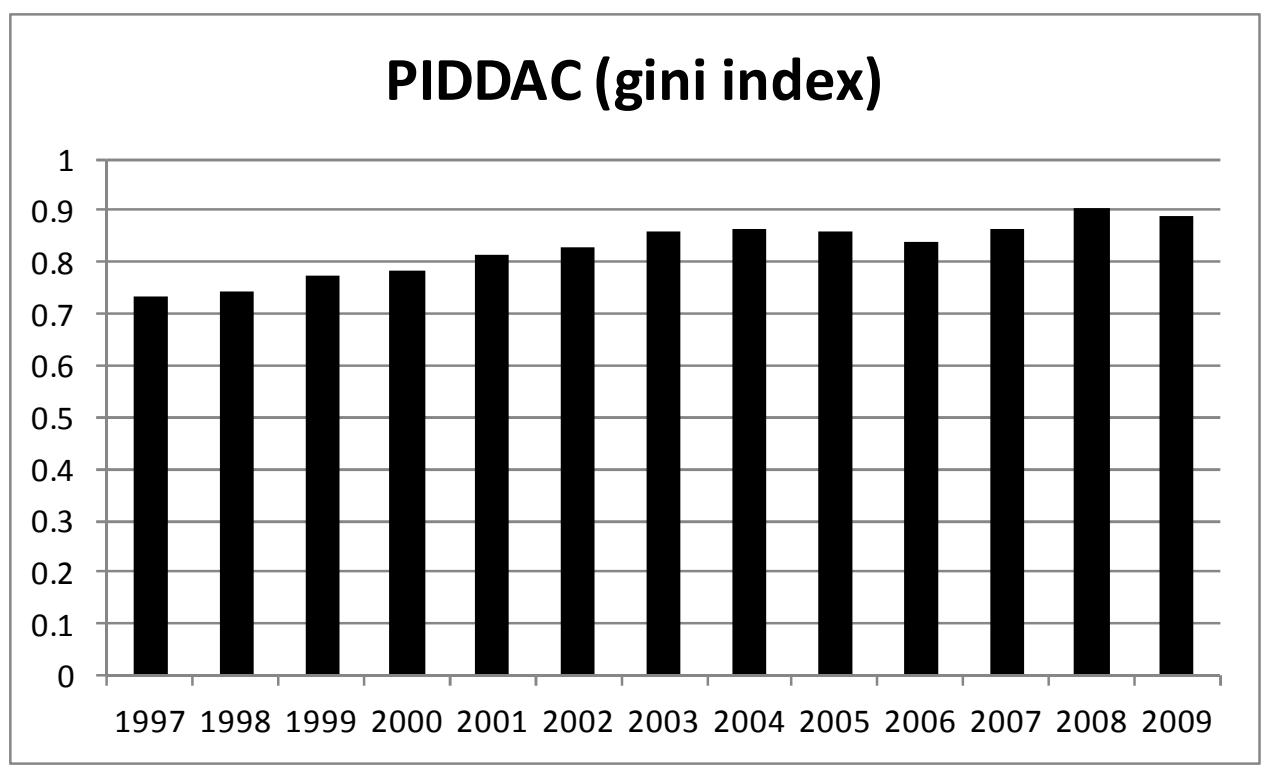

Matrix 1 - Expected payoff considering pork-barrel effects conditioned on the ruling party at National and Municipal powers

\begin{tabular}{|l|l|l|}
\hline & $\begin{array}{l}\text { Right Party at the } \\
\text { Municipality }\end{array}$ & Left Party at the Municipality \\
\hline $\begin{array}{l}\text { Right party at the } \\
\text { Government }\end{array}$ & $K^{r r}+p^{r r}$ & $K^{r l}$ \\
\hline Left Party at the Government & $K^{l r}$ & $K^{l l}+p^{l l}$ \\
\hline
\end{tabular}

Note: payoffs to the column player (Municipality) are shown

Matrix 2 - Expected payoff considering pork-barrel and irrelevance effects conditioned on the ruling party at National and Municipal powers

\begin{tabular}{|l|l|l|}
\hline & $\begin{array}{l}\text { Right Party at the } \\
\text { Municipality }\end{array}$ & Left Party at the Municipality \\
\hline $\begin{array}{l}\text { Right party at the } \\
\text { Government }\end{array}$ & $K^{r r}+p^{r r}-u^{r r}$ & $K^{r l}-u^{r l}$ \\
\hline Left Party at the Government & $K^{l r}-u^{l r}$ & $K^{l l}+p^{l l}-u^{l l}$ \\
\hline
\end{tabular}

Note: payoffs to the Municipality, given the irrelevance charged to that Municipality, are shown 
Table 2 - Variables and Sources

\begin{tabular}{|l|l|}
\hline Variable & Source \\
\hline PIDDAC amounts & Portuguese Republic Budget Report (2002-2009) \\
\hline Municipal Executive mandates & $\begin{array}{l}\text { Municipal Electoral results, 2002-2009 (available at } \\
\text { http://www.dgai.mai.gov.pt/?area=103\&mid=001\&sid=003) }\end{array}$ \\
\hline Municipal Assembly seats & $\begin{array}{l}\text { Municipal Electoral results, 2002-2009 (available at } \\
\text { http://www.dgai.mai.gov.pt/?area=103\&mid=001\&sid=003) }\end{array}$ \\
\hline Percentage of parishes & $\begin{array}{l}\text { National Bureau of Statistics (INE), 2002-2009 (Yearly } \\
\text { Regional Reports) }\end{array}$ \\
\hline Population density & $\begin{array}{l}\text { National Bureau of Statistics (INE), 2002-2009 (Yearly } \\
\text { Regional Reports) }\end{array}$ \\
\hline Percentage of people older than & $\begin{array}{l}\text { National Bureau of Statistics (INE), 2002-2009 (Yearly } \\
\text { Regional Reports) }\end{array}$ \\
\hline Legislative Electoral years & $\begin{array}{l}\text { National Bureau of Statistics (INE), 2002-2009 (Yearly } \\
\text { Regional Reports) }\end{array}$ \\
\hline
\end{tabular}

Matrix 3 - Estimated PIDDAC for a municipality i (log values) considering pork-barrel and irrelevance effects conditioned on the ruling party at National and Municipal powers

\begin{tabular}{|c|c|c|}
\hline & Right Party at the Municipality $\mathrm{i}$ & Left Party at the Municipality i \\
\hline $\begin{array}{l}\text { Right party } \\
\text { at the } \\
\text { Government }\end{array}$ & 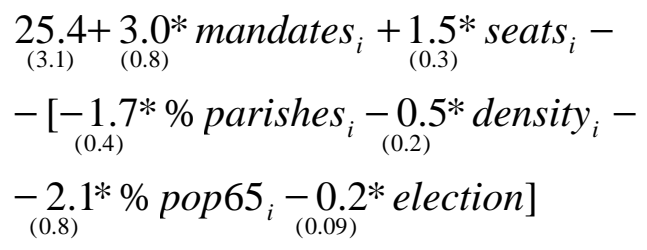 & $\begin{array}{l}\underset{(2.01)}{17.0+\underset{(0.4)}{0.7 *} \text { mandates }_{i}-} \\
-\underset{(0.3)}{-0.6^{*} \% \text { parishes }_{i}}-\underset{(0.4)}{\left.0.8^{*} \text { Density }_{i}\right)}\end{array}$ \\
\hline $\begin{array}{l}\text { Left Party at } \\
\text { the } \\
\text { Government }\end{array}$ & $\begin{array}{l}17.0 \\
(2.2) \\
-\underset{(0.2)}{-0.6^{*} \% \text { parishes }_{i}}-\underset{(0.1)}{0.7 * \text { density }_{i}-} \\
-\underset{(0.2)}{\left.0.5^{*} \text { election }\right]}\end{array}$ & $\begin{array}{l}\underset{(3.8)}{13.9+} \underset{(1.1)}{3.8^{*} \text { mandates }_{i}-} \\
\left.-\underset{(0.2)}{-0.4^{*}} \text { election }\right]\end{array}$ \\
\hline
\end{tabular}

Notes: Standard errors between parentheses. Check Table 4. 
Table 3 - Descriptive statistics

\begin{tabular}{|c|c|c|c|c|c|c|c|c|}
\hline & & PIDDAC (In) & mandates (In) & seats (In) & \%parishes (In) & pop.density(In) & \%pop65(In) & leg.election \\
\hline \multirow{5}{*}{$\begin{array}{l}\text { All sample } \\
\text { (1997-2009) }\end{array}$} & \multirow{2}{*}{$\begin{array}{l}\text { Observations } \\
\text { Mean }\end{array}$} & 3200 & 3328 & 3036 & 3464 & 3464 & 3464 & 3464 \\
\hline & & 13.316 & 0.989 & 1.477 & -6.077 & 4.414 & -1.602 & 0.375 \\
\hline & \multirow{3}{*}{$\begin{array}{l}\text { Std.Dev. } \\
\text { Min. } \\
\text { Max. }\end{array}$} & 2.186 & 0.517 & 0.947 & 0.856 & 1.436 & 0.307 & 0.484 \\
\hline & & 4.466 & 0 & 0 & -8.357 & 1.662 & -2.495 & 0 \\
\hline & & 20.229 & 2.079 & 4.174 & -3.867 & 8.903 & -0.863 & 1 \\
\hline \multirow{5}{*}{$\begin{array}{l}\text { Left Munic. } \\
\text { Left Gov. } \\
\text { (1997-2009) }\end{array}$} & \multirow{2}{*}{$\begin{array}{l}\text { Observations } \\
\text { Mean }\end{array}$} & 486 & 578 & 585 & 568 & 568 & 568 & 568 \\
\hline & & 12.807 & 1.367 & 1.853 & -6.077 & 4.245 & -1.562 & 0.25 \\
\hline & \multirow{2}{*}{$\begin{array}{l}\text { Std.Dev. } \\
\text { Min. }\end{array}$} & 2.332 & 0.219 & 0.825 & 0.887 & 1.383 & 0.319 & 0.433 \\
\hline & & 6.908 & 1.099 & 0 & -8.357 & 1.714 & -2.495 & 0 \\
\hline & Max. & 17.876 & 1.792 & 3.806 & -3.868 & 8.891 & -0.874 & 1 \\
\hline \multirow{5}{*}{$\begin{array}{l}\text { Right Muni. } \\
\text { Left Gov. } \\
\text { (1997-2009) }\end{array}$} & \multirow{5}{*}{$\begin{array}{l}\text { Observations } \\
\text { Mean } \\
\text { Std.Dev. } \\
\text { Min. } \\
\text { Max. }\end{array}$} & 995 & 1144 & 978 & 1164 & 1164 & 1164 & 1164 \\
\hline & & 12.923 & 0.713 & 1.007 & -6.075 & 4.495 & -1.605 & 0.250 \\
\hline & & 2.322 & 0.439 & 0.845 & 0.836 & 1.471 & 0.286 & 0.433 \\
\hline & & 5.481 & 0.000 & 0.000 & -8.357 & 1.663 & -2.477 & 0.000 \\
\hline & & 19.663 & 1.792 & 3.178 & -4.297 & 8.699 & -0.925 & 1.000 \\
\hline \multirow{6}{*}{$\begin{array}{l}\text { Left Muni. } \\
\text { Right Gov. } \\
\text { (1997-2009) }\end{array}$} & & & & & & & & \\
\hline & \multirow{5}{*}{$\begin{array}{l}\text { Observat } \\
\text { Mean } \\
\text { Std.Dev. } \\
\text { Min. } \\
\text { Max. }\end{array}$} & 921 & 761 & 596 & 900 & 900 & 900 & 900 \\
\hline & & 13.755 & 0.659 & 1.146 & -6.183 & 4.396 & -1.597 & 0.5 \\
\hline & & 2.003 & 0.495 & 0.891 & 0.891 & 1.539 & 0.299 & 0.5 \\
\hline & & 5.891 & 0 & 0 & -8.355 & 1.801 & -2.392 & 0 \\
\hline & & 20.229 & 2.079 & 3.135 & -4.135 & 8.904 & -0.863 & 1 \\
\hline \multirow{5}{*}{$\begin{array}{l}\text { Right Muni. } \\
\text { Right Gov. } \\
(1997-2009)\end{array}$} & \multirow{5}{*}{$\begin{array}{l}\text { Observations } \\
\text { Mean } \\
\text { Std.Dev. } \\
\text { Min. } \\
\text { Max. }\end{array}$} & 799 & 846 & 877 & 832 & 832 & 832 & 832 \\
\hline & & 13.607 & 1.401 & 1.977 & -5.966 & 4.437 & -1.628 & 0.498 \\
\hline & & 1.966 & 0.261 & 0.809 & 0.808 & 1.290 & 0.332 & 0.501 \\
\hline & & 4.466 & 1.099 & 0 & -8.355 & 1.761 & -2.491 & 0 \\
\hline & & 18.229 & 2.079 & 4.174 & -3.867 & 8.213 & -0.918 & 1 \\
\hline
\end{tabular}


Table 4 - Maximum Likelihood Estimations (Dependent variable: PIDDAC (In) received by each municipality)

\begin{tabular}{|c|c|c|c|c|c|}
\hline & & $\begin{array}{l}\text { Left Munic. } \\
\text { Left Gov. } \\
\text { (1997-2009) }\end{array}$ & $\begin{array}{l}\text { Right Muni. } \\
\text { Left Gov. } \\
\text { (1997-2009) }\end{array}$ & $\begin{array}{l}\text { Left Muni. } \\
\text { Right Gov. } \\
\text { (1997-2009) }\end{array}$ & $\begin{array}{l}\text { Right Muni. } \\
\text { Right Gov. } \\
\text { (1997-2009) }\end{array}$ \\
\hline & Constant & $\begin{array}{c}13.906 * * * \\
(3.802) \\
\end{array}$ & $\begin{array}{c}17.019^{* * * *} \\
(2.198) \\
\end{array}$ & $\begin{array}{c}16.964^{* * * *} \\
(1.968) \\
\end{array}$ & $\begin{array}{c}25.426^{* * *} \\
(3.099) \\
\end{array}$ \\
\hline \multirow{2}{*}{$\begin{array}{l}\text { (1st equation) } \\
\text { Dependent Variable: } \\
\text { PIDDAC (In) }\end{array}$} & mandates (In) & $\begin{array}{c}3.760^{* * *} \\
(1.114) \\
\end{array}$ & $\begin{array}{r}0.445 \\
(0.386) \\
\end{array}$ & $\begin{array}{l}0.727^{*} \\
(0.388) \\
\end{array}$ & $\begin{array}{c}2.989^{* * *} \\
(0.832) \\
\end{array}$ \\
\hline & seats (In) & $\begin{array}{l}-0.232 \\
(0.458) \\
\end{array}$ & $\begin{array}{c}0.011 \\
(0.226) \\
\end{array}$ & $\begin{array}{l}-0.031 \\
(0.249) \\
\end{array}$ & $\begin{array}{c}1.462^{* * *} \\
(0.338) \\
\end{array}$ \\
\hline \multirow{9}{*}{$\begin{array}{l}\text { (2nd equation) } \\
\text { Dependent Variable: } \\
\text { uit }\end{array}$} & \%parishes (In) & $\begin{array}{r}0.512 \\
(0.425) \\
\end{array}$ & $\begin{array}{c}-0.599^{* * *} \\
(0.220) \\
\end{array}$ & $\begin{array}{c}-0.643^{* * *} \\
(0.251) \\
\end{array}$ & $\begin{array}{c}-1.727^{* * *} \\
(0.354) \\
\end{array}$ \\
\hline & pop.density(In) & $\begin{array}{c}0.291 \\
(0.221) \\
\end{array}$ & $\begin{array}{c}-0.734^{* * *} \\
(0.140) \\
\end{array}$ & $\begin{array}{c}-0.763^{* * *} \\
(0.388) \\
\end{array}$ & $\begin{array}{c}-0.548^{* *} \\
(0.233) \\
\end{array}$ \\
\hline & \%pop65(In) & $\begin{array}{r}-0.040 \\
(0.898) \\
\end{array}$ & $\begin{array}{r}0.371 \\
(0.674) \\
\end{array}$ & $\begin{array}{r}0.676 \\
(0.563) \\
\end{array}$ & $\begin{array}{c}-2.103^{* * *} \\
(0.762) \\
\end{array}$ \\
\hline & |leg.election & $\begin{array}{c}-0.368^{* *} \\
(0.177) \\
\end{array}$ & $\begin{array}{c}-0.455^{* * *} \\
(0.150)\end{array}$ & $\begin{array}{c}0.098 \\
(0.113)\end{array}$ & $\begin{array}{c}-0.232^{* * *} \\
(0.087) \\
\end{array}$ \\
\hline & Number of Observ & 429 & 961 & 893 & 745 \\
\hline & Number of Groups & 95 & 157 & 99 & 141 \\
\hline & Sigma squared & $\begin{array}{c}3.693 \\
(0.305) \\
\end{array}$ & $\begin{array}{c}3.997 \\
(0.348) \\
\end{array}$ & $\begin{array}{c}2.453 \\
(0.309) \\
\end{array}$ & $\begin{array}{c}4.171 \\
(1.377) \\
\end{array}$ \\
\hline & Gamma & $\begin{array}{c}0.533 \\
(0.058) \\
\end{array}$ & $\begin{array}{r}0.464 \\
(0.051) \\
\end{array}$ & $\begin{array}{c}0.486 \\
(0.068)\end{array}$ & $\begin{array}{c}0.755 \\
(0.082)\end{array}$ \\
\hline & Log-likelihood & -630.58 & -1116.72 & -676.81 & -919.94 \\
\hline
\end{tabular}

Notes: Standard errors between parentheses

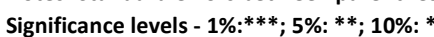

